\title{
Low Mean Cell Haemoglobin is a Valuable Parameter of Thrombotic Risk Stratification in Patients with Polycythemia Vera
}

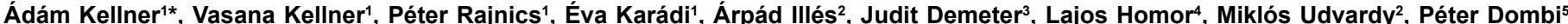
Hajnalka Andrikovics ${ }^{6}$, József Herczeg ${ }^{1}$ and Miklós Egyed ${ }^{1}$

${ }^{1}$ Department of Haematology, Somogy County Kaposi Mór Teaching Hospital, Kaposvár, Hungary

${ }^{2}$ Department of Haematology, University of Debrecen Faculty of Medicine, Debrecen, Hungary

${ }^{3}$ First Department of Internal Medicine, Division of Haematology, Semmelweis University, Budapest, Hungary

${ }^{4}$ Faculty of Humanities and Social Sciences, Pázmány Peter Catholic University, Budapest, Hungary

${ }^{5}$ Department of Haematology, Szent Borbála County Hospital, Tatabánya, Hungary

${ }^{6}$ Hungarian National Blood Transfusion Service, Laboratory of Molecular Diagnostics, Budapest, Hungary

\begin{abstract}
Objectives: Thrombosis is a leading cause of morbidity and mortality in patients with Philadelphia negative chronic myeloproliferative neoplasms (MPNs). There are many thrombosis risk stratifications used in this patient group taking into consideration the age, thrombosis history and cardiovascular factors (hypertension, hypercholesterinaemia, hyper-trigliceridaemia, thrombocytosis, smoking and diabetes mellitus). In this work we evaluated the possible role of iron deficiency in thrombotic events (TE) of the polycythaemia vera (PV) patients. Methods: We considered the low mean cell haemoglobin $(\mathrm{MCH}<28 \mathrm{pg})$ value as a parameter to assess the iron deficiency in the multicentre database (15 Hungarian haematology centres) of our HUMYPRON GROUP (Hungarian MPN Working Group). The MCH values, recorded at the time of diagnosis of 296 patients with polycythemia vera, were retrospectively analysed.
\end{abstract}

Results: The low $\mathrm{MCH}$, at the diagnosis, was found to be a risk factor for thrombotic events occurring after diagnosis (OR: 1.966). It was also shown as an additive and independent parameter in the Tefferi high-risk patient groups, and combining it with Tefferi risk stratification an extremely high thrombotic risk group could be determined (Nagelkerke R square: 0.084 ). We have supposed that low MCH in PV reveals a disease form featured with a high proliferation activity. Our hypothesis was confirmed with a sub-study $(n=52)$ showing that the high JAK2 ${ }^{\mathrm{V} 617 \mathrm{~F}}$ allele burden was significantly correlated with the low $\mathrm{MCH}(p=0.005)$ and the high white blood cell count $(\mathrm{WBC})(\mathrm{p}<0.001)$

Conclusions: Iron deficiency, existing at the time of diagnosis of PV, was proven to be a risk factor for imminent thrombotic events. The low $\mathrm{MCH}$ was found to be a strong additive factor when it was combined with the known thrombotic risk stratification systems. The low $\mathrm{MCH}$ showed significant correlation with the high JAK2 ${ }^{\mathrm{V} 617 \mathrm{~F}}$ allele burden.

Keywords: Iron deficiency; Mean cell haemoglobin; Myeloproliferative neoplasms; Polycythemia vera; Thrombotic risk

\section{Introduction}

Philadelphia negative chronic myeloproliferative neoplasms (polycythemia vera (PV), essential thrombocythemia (ET) and primary myelofibrosis (PMF)) are associated with higher thrombotic risk leading to excessive cardiovascular mortality [1-4].

A comprehensive epidemiological study involving PV patients, the European collaboration study on low dose aspirin in polycythemia (ECLAP), revealed that $41 \%$ of all mortality was of cardiovascular origin (1.5 deaths per 100 person per year). Coronary heart disease was responsible for $15 \%$ of all deaths, whereas congestive heart failure, non-haemorrhagic stroke and pulmonary embolism accounted for $8-8 \%$ each. The cumulative incidence of nonfatal thrombosis was 3.8 events per 100 people per year, without a difference between arterial and venous thrombosis [5].

The thrombophilic behaviour observed in these conditions manifests in microcirculatory disturbances, arterial and venous thrombosis. The possible mechanism resulting in thrombophilia in MPN patients has been widely investigated over the last decades, nevertheless there is no definite answer that could explain this phenomenon. Data from earlier studies are often conflicting or difficult to interpret. For instance, both the iron deficiency and the excess have been associated with increased thrombotic risk [6].

Epidemiological studies support the hypothesis of Sullivan [7], that elevated level of stored iron associates with higher incidence of cardiovascular morbidity [8-10]. However, iron deficiency was recognised as a risk factor of cerebral sinus thrombosis [11], carotid artery thrombosis [12], central retinal vein occlusion [13,14] and superior sagittal sinus thrombosis [15].

Donovan et al. [16] found that PV patients treated with phlebotomy alone suffered significantly more thrombotic events than those who received myelosuppressive regimens [17]. Iron deficiency is commonly detected in patients with PV. The phlebotomy can contribute to the further worsening of iron deficiency [18].

There is different risk stratifications used to assess the thrombotic risk at the time of diagnosis in clinical practice of Philadelphia negative MPNs. The risk stratification proposed by Tefferi estimates the

*Corresponding author: Ádám Kellner, Department of Hematology, Somogy County Kaposi Mór Teaching Hospital, 7400 Kaposvár, Tallián Gy. u. 20-32, Hungary, Tel: +3682/501341; E-mail: adamkellner11@gmail.com

Received January 23, 2018; Accepted February 09, 2018; Published February 16, 2018

Citation: Kellner A, Kellner V, Rajnics P, Karádi E, Illés A, et al. (2018) Low Mean Cell Haemoglobin is a Valuable Parameter of Thrombotic Risk Stratification in Patients with Polycythemia Vera. J Blood Lymph 8: 207. doi:10.4172/21657831.1000207

Copyright: $\odot 2018$ Kellner A, et al. This is an open-access article distributed unde the terms of the Creative Commons Attribution License, which permits unrestricted use, distribution, and reproduction in any medium, provided the original author and source are credited. 
possibility of a recurrent thrombosis in PV patients. There are two risk categories, the high (age $>60$ years or prior thrombotic event) and the low (age $\leq 60$ years and no thrombosis history) [19]. The risk analysis by Landolfi, beside these variables, also takes general vascular factors into consideration [20].

The transferrin saturation, serum ferritin level, reticulocyte haemoglobin content and bone marrow iron content are the most used and suitable parameters to measure the body's iron status nowadays. On the other hand, more reports raised attention that red blood cell hypochromia and decreased red blood cell haemoglobin content indicate the presence of iron deficiency [21-26]. The low mean cell haemoglobin content $(\mathrm{MCH})$ is an appropriate parameter which notes iron deficiency [21], and it is more available in retrospective databases in comparison to other iron status parameters.

The aim of our retrospective multicentre study was to evaluate the impact of $\mathrm{MCH}$, white blood cell count (WBC), platelet count (PLT), age and thrombotic events at the time of diagnosis and compare our findings to Tefferi and Landolfi thromboembolic risk stratifications in PV patients registered in the Hungarian Myeloproliferative Neoplasia Working Group (HUMYPRON GROUP) database [27].

\section{Materials and Methods}

After its establishment in 2012, the Hungarian MPN Working Group (HUMYPRON GROUP) introduced a simple, practical database for Philadelphia negative MPN patients with clinical and laboratory data collected from 15 Hungarian haematology centres [27].

\section{Eligibility criteria}

Eligibility criteria included the age, 18 years or older, and a previous confirmation of PV according to WHO 2008 criteria [28]. Clinical factors (age, gender, previous thrombotic history and risk stratifications by Tefferi and Landolfi and family history of thrombophilia) and laboratory parameters at diagnosis (white blood count: WBC, haemoglobin: Hb, haematocrit: Htc, mean cell haemoglobin: $\mathrm{MCH}$, platelet: PLT and C-reactive protein: $\mathrm{CRP}$ ) were collected. We used MCH value to assess the iron status at the time of MPN diagnosis. We excluded patients with thalassemia, myelofibrosis and end-stage kidney disease whose $\mathrm{MCH}$ alterations might have been associated with the original disease and not with the iron deficiency.

\section{Diagnosis of thrombosis}

Vascular thrombosis was defined according to Gisslinger et al. [29]. Major events included the following complications: peripheral vascular (peripheral arterial thrombosis, deep venous thrombosis and pulmonary thromboembolism), cardiovascular (myocardial infarction), central nervous system (stroke, retinal vessel thrombosis and sinus thrombosis) and intra-abdominal vascular events (splenicportal vein thrombosis and Budd-Chiari syndrome). Minor events were angina pectoris, transient ischemic attack and superficial thrombophlebitis of the extremities, and they were taken into account only in patients who had no other major thrombotic events. Visual complaint, headache, dizziness, tinnitus or acroparesthesia were not considered as thrombotic events.

JAK2 ${ }^{\mathrm{V} 617 \mathrm{~F}}(\mathrm{c} .1849 \mathrm{G}>\mathrm{T})$ activating mutation was screened by allelespecific polymerase chain reaction (PCR) [30]. In a subgroup of the JAK2 ${ }^{\mathrm{V} 617 \mathrm{~F}}$ mutant cases, real-time quantitative PCR was performed to determine the V617F allele burden [31].

\section{Ethics and study management}

The study was conducted according to the good clinical practice rules and the principles of the Helsinki Declaration. Written informed consent was obtained from the subjects for using their data anonymously after explaining them the purpose and nature of the study.

\section{Statistical Analysis}

Fisher's exact test was used to compare dichotomous variables, while Mann-Whitney test served to analyse continuous variables. Studying the development of thrombotic events, odd's ratios (OR) and $95 \%$ confidence intervals (95\%CIs) were calculated by logistic regression in different subgroups according to the gender, age, diagnosis, previous thrombotic history, JAK2V617F, WBC, MCH, PLT, Landolfi and Tefferi risk groups. Only those factors which exerted significant impact on univariate analysis were involved in multivariable tests. As the previous thrombotic event, as a parameter, is involved in the Landolfi and Tefferi risk stratifications, it was not separately included in multivariable analyses. Statistical analyses were performed using IBM SPSS 24.0 and Social Science Statistics software package (www.socscistatistics.com). The cut-off value of significance was $\mathrm{p}<0.05$.

\section{Results}

Data of 296 PV patients were available from the date of diagnosis, allowing us to identify thromboembolic events throughout the following period of 61 months on average. Median age was 61.4 years and male dominance was observed. Only JAK2 ${ }^{\mathrm{V} 617 \mathrm{~F}}$ or exon 12 mutated patients were included. We adopted both the Landolfi and Tefferi risk analyses with the simplification of using only two categories (low and high risks) (Table 1).

Altogether 99 thromboembolic events were observed in 82 patients between date of diagnosis and date of study entry. Low $\mathrm{MCH}$ value

\begin{tabular}{|c|c|c|}
\hline & \multicolumn{2}{|c|}{ PV (n=296) } \\
\hline & No. of pts. & $\%$ \\
\hline \multicolumn{3}{|l|}{ Sex } \\
\hline Male & 169 & $57.09 \%$ \\
\hline Female & 127 & $42.91 \%$ \\
\hline \multicolumn{3}{|l|}{ Previous TE event } \\
\hline No & 224 & $75.68 \%$ \\
\hline Yes & 72 & $24.32 \%$ \\
\hline \multicolumn{3}{|l|}{$\mathrm{MCH}$} \\
\hline Low $(<28$ pg) & 95 & $32.09 \%$ \\
\hline Not low $(\geq 28 \mathrm{pg})$ & 201 & $67.91 \%$ \\
\hline \multicolumn{3}{|l|}{ WBC } \\
\hline Not high $\left(\leq 10 \times 10^{9} / \mathrm{l}\right)$ & 125 & $42.23 \%$ \\
\hline High $\left(>10 \times 10^{9} / I\right)$ & 171 & $57.77 \%$ \\
\hline \multicolumn{3}{|l|}{ PLT } \\
\hline Not high $\left(\leq 450 \times 10^{9} / I\right)$ & 152 & $51.35 \%$ \\
\hline High $\left(>450 \times 10^{9} / \mathrm{l}\right)$ & 144 & $48.65 \%$ \\
\hline \multicolumn{3}{|l|}{ Landolfi risk } \\
\hline Low (low+intermediate risk) & 69 & $23.31 \%$ \\
\hline High (high+very high risk) & 227 & $76.69 \%$ \\
\hline \multicolumn{3}{|l|}{ Tefferi risk } \\
\hline Low & 113 & $38.18 \%$ \\
\hline High & 183 & $61.82 \%$ \\
\hline \multicolumn{3}{|c|}{ Median age at the diagnosis (years) } \\
\hline Male & \multicolumn{2}{|c|}{59.6} \\
\hline Female & \multicolumn{2}{|c|}{63.9} \\
\hline
\end{tabular}

Table 1: Sex, TE history, WBC, MCH, PLT, Landolfi- and Tefferi-risk, median age at the diagnosis in patients with $P V(n=296)$. 
Citation: Kellner A, Kellner V, Rajnics P, Karádi E, Illés A, et al. (2018) Low Mean Cell Haemoglobin is a Valuable Parameter of Thrombotic Risk Stratification in Patients with Polycythemia Vera. J Blood Lymph 8: 207. doi:10.4172/2165-7831.1000207

Page 3 of 6

$(<28 \mathrm{pg})$ was found in 36 patients. The male/female ratio, median age, median follow up, Tefferi- and Landolfi risk results were similar in the groups of low and normal/high MCH values ( $\geq 28 \mathrm{pg}$ ) (Table 2).

Univariate analysis found significant correlation between the thromboembolic events and the previous thrombosis history, high Tefferi and Landolfi risk groups, high WBC as well as low $\mathrm{MCH}$ value. No other parameter was found to correlate with thromboembolic events (Table 3).

\begin{tabular}{|c|c|c|c|c|c|}
\hline & \multicolumn{2}{|c|}{ Low MCH (n=95) } & \multicolumn{2}{|c|}{ Normal/high MCH $(n=201)$} & \multirow[b]{2}{*}{$\mathbf{p}$} \\
\hline & No. of pts. & $\%$ & No. of pts. & $\%$ & \\
\hline \multicolumn{6}{|l|}{ Sex } \\
\hline Male & 49 & $51.58 \%$ & 120 & $59.70 \%$ & \multirow[t]{2}{*}{0.209} \\
\hline Female & 46 & $48.42 \%$ & 81 & $40.30 \%$ & \\
\hline \multicolumn{6}{|l|}{ Landolfi risk } \\
\hline $\begin{array}{l}\text { Low (low+intermediate } \\
\text { risk) }\end{array}$ & 20 & $21.05 \%$ & 49 & $24,38 \%$ & \multirow[t]{2}{*}{0.559} \\
\hline High (high+very high risk) & 75 & $78.95 \%$ & 152 & $75.62 \%$ & \\
\hline \multicolumn{6}{|l|}{ Tefferi risk } \\
\hline Low & 31 & $32.63 \%$ & 82 & $40.80 \%$ & \multirow[t]{2}{*}{0.201} \\
\hline High & 64 & $67.37 \%$ & 119 & $59.20 \%$ & \\
\hline \multicolumn{6}{|c|}{ Pts. having TE after diagnosis } \\
\hline Yes & 35 & $36.84 \%$ & 46 & $22.89 \%$ & \multirow[t]{2}{*}{0.017} \\
\hline No & 60 & $63.16 \%$ & 155 & $77.11 \%$ & \\
\hline Minor arterial events & \multicolumn{2}{|l|}{25} & \multicolumn{2}{|c|}{24} & \\
\hline Major arterial events & \multicolumn{2}{|l|}{1} & \multicolumn{2}{|c|}{5} & \\
\hline Minor venous events & \multicolumn{2}{|l|}{20} & \multicolumn{2}{|c|}{22} & \\
\hline Major venous events & \multicolumn{2}{|l|}{8} & \multicolumn{2}{|c|}{17} & \\
\hline Median age (years) & \multicolumn{2}{|l|}{62.5} & \multicolumn{2}{|c|}{60.9} & \\
\hline Follow up (months) & \multicolumn{2}{|l|}{60} & \multicolumn{2}{|c|}{62} & \\
\hline
\end{tabular}

Table 2: Comparison of the TE events, Tefferi- and Landolfi risk, sex, median age median follow up in low $\mathrm{MCH}(<28 \mathrm{pg})$ and normal/high $\mathrm{MCH}(\geq 28 \mathrm{pg})$ groups.

\begin{tabular}{|c|c|c|c|c|}
\hline $\begin{array}{l}\text { Univariate } \\
\text { analysis }(n=296)\end{array}$ & $\begin{array}{c}\text { TE events } \\
(n=81)\end{array}$ & $\begin{array}{c}\text { no TE events } \\
(n=215)\end{array}$ & OR (Cl 95\%) & p \\
\hline \multicolumn{3}{|l|}{ Sex } & \multirow[t]{3}{*}{$1.502(0.887-2.545)$} & \multirow[t]{3}{*}{0.13} \\
\hline male & $52(64 \%)$ & $117(54 \%)$ & & \\
\hline female & $29(36 \%)$ & $98(46 \%)$ & & \\
\hline \multicolumn{3}{|l|}{ Age } & \multirow[t]{3}{*}{$1.265(0.754-2.123)$} & \multirow[t]{3}{*}{0.374} \\
\hline$>60$ years & $48(59 \%)$ & $115(53 \%)$ & & \\
\hline$\leq 60$ years & $33(41 \%)$ & $100(47 \%)$ & & \\
\hline \multicolumn{3}{|l|}{ Previous TE } & \multirow[t]{3}{*}{$12.783(6.870-23.782)$} & \multirow[t]{3}{*}{$<0.001$} \\
\hline yes & $49(60 \%)$ & $23(11 \%)$ & & \\
\hline no & $32(40 \%)$ & $192(89 \%)$ & & \\
\hline \multicolumn{3}{|l|}{ WBC } & \multirow[t]{3}{*}{$1.948(1.133-3.350)$} & \multirow[t]{3}{*}{0.015} \\
\hline high & $56(69 \%)$ & $115(53 \%)$ & & \\
\hline not high & $25(31 \%)$ & $100(47 \%)$ & & \\
\hline \multicolumn{3}{|l|}{$\mathrm{MCH}$} & \multirow[t]{3}{*}{$1.966(1.156-3.343)$} & \multirow[t]{3}{*}{0.012} \\
\hline low & $35(43 \%)$ & $60(28 \%)$ & & \\
\hline not low & $46(57 \%)$ & $155(72 \%)$ & & \\
\hline \multicolumn{3}{|l|}{ PLT } & \multirow[t]{3}{*}{$1.041(0.625-1.736)$} & \multirow[t]{3}{*}{0.877} \\
\hline high & $40(49 \%)$ & $104(48 \%)$ & & \\
\hline not high & $41(51 \%)$ & $111(52 \%)$ & & \\
\hline \multicolumn{3}{|l|}{ Landolfi } & \multirow[t]{3}{*}{$3.614(1.644-7.947)$} & \multirow[t]{3}{*}{$<0.001$} \\
\hline high & $73(90 \%)$ & $154(72 \%)$ & & \\
\hline not high & $8(10 \%)$ & $61(28 \%)$ & & \\
\hline \multicolumn{3}{|l|}{ Tefferi } & \multirow[t]{3}{*}{$2.771(1.538-4.993)$} & \multirow[t]{3}{*}{$<0.001$} \\
\hline high & $63(78 \%)$ & $120(56 \%)$ & & \\
\hline not high & $18(22 \%)$ & $95(44 \%)$ & & \\
\hline
\end{tabular}

Table 3: Univariate analysis of factors measured at the time of diagnosis affecting thrombotic risk (WBC high: $>10 \times 10^{9} /$; WBC not high: $\leq 10 \times 10^{9} / \mathrm{l} ; \mathrm{MCH}$ low: $<28$ pg; $\mathrm{MCH}$ not low: $\geq 28$ pg; PLT high: $>450 \times 10^{9} /$; PLT not high: $\left.\leq 450 \times 10^{9} / \mathrm{l}\right)$.
After diagnosis, most patients were treated with the combination of hydroxiurea and aspirin. No conclusion could have been drawn from the treatment effect on thrombotic risk, as the follow-up period was long and the patients usually received more than one therapies.

Multivariable analysis revealed that the low $\mathrm{MCH}$ is an independent risk factor for thrombotic events. An additive effect to Tefferi risk was observable regarding both $\mathrm{WBC}$ and $\mathrm{MCH}$. Male gender, together with the other three factors, also has a significant effect (Table 4).

The low $\mathrm{MCH}$ level may be resulted by an interaction between the high proliferation activity and the iron demand. Supporting our hypothesis, we analysed a random subgroup $(n=52)$ of 296 patients. The consistency of this subgroup did not differ in age, gender or any other parameters from the group which had been originally examined. The average age was 63.9 years. The distribution of female and male patients was $46 \%$ and $54 \%$, respectively. Comparing JAK2V617F allele burden to $\mathrm{MCH}$ value and white blood cell count, we found that, the incidence of low $\mathrm{MCH}$ and high WBC was significantly higher in cases featured with the high JAK2V617F burden (Figures 1 and 2 and Table $5)$. In those patients whose JAK2V617F allele burden has exceeded $20 \%$ the low HCH occurred in a significantly higher proportion $(\mathrm{p}=0.005)$.

A similar rise, though a less remarkable, was found regarding WBC count $(\mathrm{p}<0.001)$.

26 of the 34 patient with elevated WBC $\left(>10 \times 10^{9} / 1\right)$ had low $\mathrm{MCH}$ $(<28 \mathrm{pg})$, while only 8 of 18 patient with low WBC $\left(\leq 10 \times 10^{9} / \mathrm{l}\right)$ had low $\mathrm{MCH}(\mathrm{p}=0.021)$.

\section{Discussion}

According to our current knowledge, the thrombophilic state observed in myeloproliferative neoplasms is of multifactorial origin. The previous thrombotic event, elevated WBC, high JAK2 ${ }^{\mathrm{V} 617 \mathrm{~F}}$ allele burden, advanced age, high body mass index (BMI), hypertension, type II diabetes mellitus and hyperlipidaemia are acknowledged as contributors of the increased thrombotic risk [20].

Clinical observations indicate that the course of $\mathrm{PV}$ is individually different. The proliferation rate of erythroid precursors in PV is higher in some patients than in the others. The low $\mathrm{MCH}$ suggests that the erythropoesis in PV exceeds the amount of available iron thus the

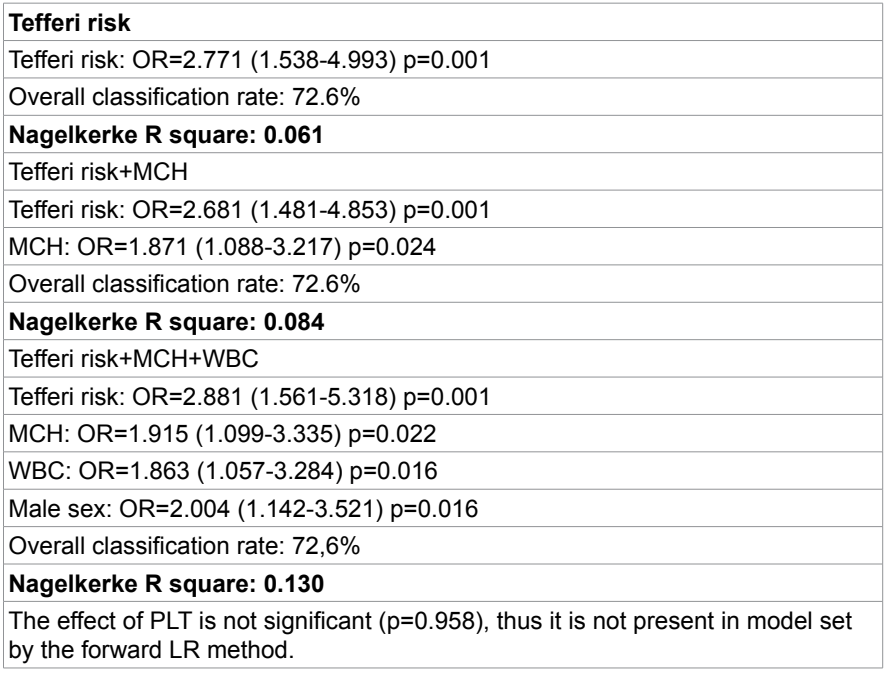

Table 4: The additional effect of low MCH and WBC to Tefferi risk stratifications in TE events (forward LR method). Nagelkerke R square means the proportion of the thrombotic event which is explained by the variables in the model. 


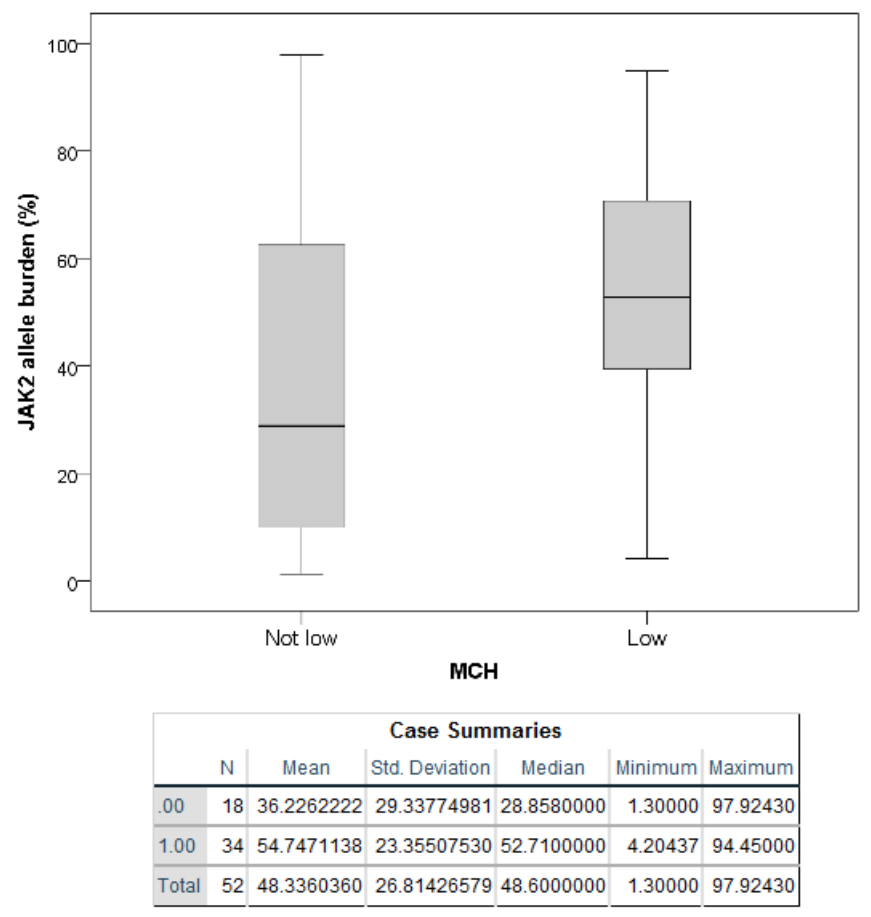

Figure 1: JAK2 ${ }^{\mathrm{V} 617 \mathrm{~F}}$ allele burden correlation with $\mathrm{MCH}$ (Mann-Whitney test, $\left.\mathrm{p}=0.021\right)$.

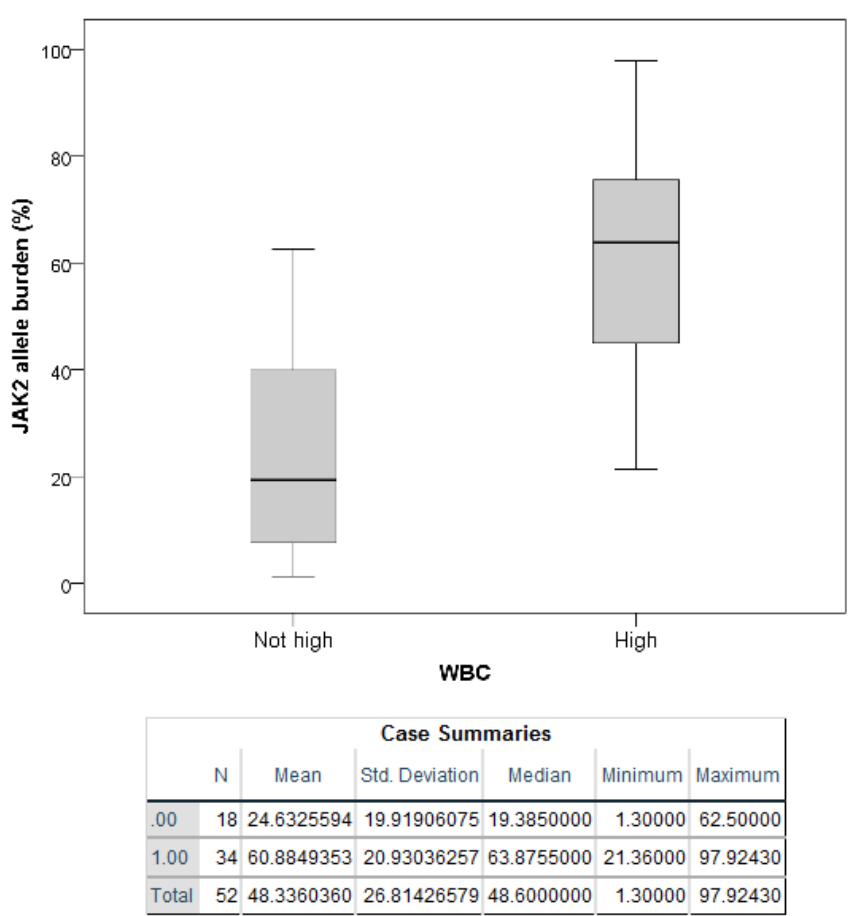

Figure 2: JAK2 ${ }^{\mathrm{V} 617 \mathrm{~F}}$ allele burden correlation with WBC (Mann-Whitney test, $\left.p<0.001\right)$.

produced erythroid mass becomes iron depleted. Our analysis has proved that the low $\mathrm{MCH}$ is a sign of the high proliferation rate in PV.

We consider that the iron deficiency exists in the background of the low MCH level [21-26]. The incidence of thromboembolic events was significantly higher in the low MCH group, supporting our hypothesis that low $\mathrm{MCH}$ is an independent risk factor for TE morbidity.
Possible pathogenic mechanisms which explain the role of iron deficiency in thromboembolic events include reactive thrombocytosis caused by iron deficiency [6], blood flow pattern alterations due to the reduced deformability and increased viscosity of microcytic red blood cells [32] and the metabolic stress increase because of the anaemic hypoxia [33]. Thus, alterations in platelet count and function may 


\begin{tabular}{|c|c|c|c|}
\hline \multirow[t]{2}{*}{$n=52$} & \multicolumn{2}{|c|}{ JAK2 $^{\mathrm{V} 617 \mathrm{~F}}$ allele burden } & \multirow[t]{2}{*}{$\mathbf{p}$} \\
\hline & $<20 \%$ & $\geq 20 \%$ & \\
\hline MCH low (<28 pg) & 2 & 32 & \multirow[t]{2}{*}{0.005} \\
\hline MCH not low ( $\geq 28 p g)$ & 7 & 11 & \\
\hline WBC high $\left(>10 \times 10^{9} / I\right)$ & 0 & 34 & \multirow[t]{2}{*}{$<0.001$} \\
\hline WBC not high $\left(\leq 10 \times 10^{9} / I\right)$ & 9 & 9 & \\
\hline
\end{tabular}

Table 5: Correlation of JAK2 ${ }^{\mathrm{V} 617 \mathrm{~F}}$ allele burden with $\mathrm{MCH}$ and WBC (Fisher's exact test).

contribute to thrombus formation, especially in the presence of an underlying atherosclerotic disease [34].

In our former article, we have hypothesized that elevated lipocalin2 (LCN2) expression level in PV and ET may also play a crucial role in the development of arterial and venous thrombosis [35]. Examining LCN2 gene expression levels, we found that, the higher relative expression correlated with the occurrence of the thrombotic events. LCN2 is a small $25 \mathrm{kDa}$ glycoprotein, which was first identified as a bacteriostatic agent produced by activated neutrophils, that acts by sequestering bacterial ferric siderophores and interfering with bacterial iron uptake [36].

LCN2 binds iron particles, the siderophores, and transports them into the cells producing increased cytoplasmic iron levels [37]. Experimentally induced iron deficient anaemia resulted a marked elevation of LCN 2 expression. After phlebotomy and alimentary iron depletion in the murine model [38-40], elevated LCN 2 levels were observed in blood, spleen and liver, and at the same time, a decrease in the overall iron levels was detected. Presumably, this mechanism may be responsible for the higher efficacy of cytoreduction compared to phlebotomy and therefore frequent phlebotomy is not recommended.

According to our hypothesis, the excessive cell turnover found in PV patients (erythropoesis) consumes iron and decreases its level. This leads to overexpression of LCN2 in the neutrophil granulocytes transporting iron into endothelium. The resulted significant increase in endothelial cytoplasmic iron levels (labile iron) leads to oxidative stress induction in the endothelial cells and contributes to the development of thrombosis.

\section{Conclusions}

Earlier publications proved that PV patients had an iron deficiency because of elevated red blood cell mass, and this condition could be corrected with cytoreductive therapy while phlebotomy might worsen it [18]. However we did not find any data in the literature if iron deficiency enhanced TE risk in patients with PV. In the HUMYPRON database, we found low MCH in 95 cases out of $296 \mathrm{PV}$ patients. After excluding patients with HD because of uraemia, thalassemia and myelofibrosis we considered the low $\mathrm{MCH}$ as a sign of iron deficiency [21]. Comparing TE events in the two groups, the patients with low $\mathrm{MCH}$ were found to have significantly more thromboembolic events. Both of the internationally accepted risk stratifications, Tefferi and Landolfi, showed significant correlation with TE events in our analysis. Using multivariable analysis, the low $\mathrm{MCH}$ was found to be independent of and additive to the Tefferi risk stratification. We have shown that low MCH among PV patients reveals a disease with high proliferation activity with an iron demand that cannot be maintained by a normal diet. We confirmed our hypothesis with a sub-study showing that the high JAK2 ${ }^{\mathrm{V} 617 \mathrm{~F}}$ allele burden was significantly correlating with the low $\mathrm{MCH}$ and the high white blood cell count.

Taking our findings in consideration we propose the phlebotomies to be performed with special attention to the iron level of those PV patients who had been diagnosed with low $\mathrm{MCH}$ (iron depletion).

\section{Limitations and Essentials}

The lack of a normal control group and its retrospective nature are the limitations of this publication. Polycythemia vera is often accompanied by thromboembolic events. We have investigated the potential role of the low mean cell haemoglobin content $(\mathrm{MCH})$. Data of 296 patients was analysed retrospectively. Low $\mathrm{MCH}$ was found to be an independent risk factor for thrombosis.

\section{References}

1. Falanga A, Marchetti M (2012) Thrombotic disease in the myeloproliferative neoplasms. ASH Education Program Book 2012: 571-581.

2. How J, Zhou A, Oh ST (2017) Splanchnic vein thrombosis in myeloproliferative neoplasms: Pathophysiology and molecular mechanisms of disease. Therapeutic Advances in Hematology 8: 107-118.

3. Passamonti F, Rumi E, Pungolino E, Malabarba L, Bertazzoni P, et al. (2004) Life expectancy and prognostic factors for survival in patients with polycythemia vera and essential thrombocythemia. The American Journal of Medicine 117: 755-761.

4. Barbui T, Carobbio A, Rambaldi A, Finazzi G (2009) Perspectives on thrombosis in essential thrombocythemia and polycythemia vera: is leukocytosis a causative factor? Blood 114: 759-763.

5. Marchioli R, Finazzi G, Landolfi R, Kutti J, Gisslinger H, et al. (2005) Vascular and neoplastic risk in a large cohort of patients with polycythemia vera. Journal of Clinical Oncology 23: 2224-2232.

6. Franchini M, Targher G, Montagnana M, Lippi G (2008) Iron and thrombosis Annals of Hematology 87: 167-173.

7. Sullivan J (1981) Iron and the sex difference in heart disease risk. The Lancet 1: $1293-1294$.

8. Lauffer RB (1991) Iron stores and the international variation in mortality from coronary artery disease. Medical Hypotheses 35: 96-102.

9. Salonen JT, Nyyssönen K, Korpela H, Tuomilehto J, Seppänen R, et al. (1992) High stored iron levels are associated with excess risk of myocardial infarction in eastern Finnish men. Circulation 86: 803-811.

10. Tuomainen TP, Punnonen K, Nyyssönen K, Salonen JT (1998) Association between body iron stores and the risk of acute myocardial infarction in men. Circulation 97: 1461-1466.

11. Benedict SL, Bonkowsky JL, Thompson JA, Van Orman CB, Boyer RS, et al (2004) Cerebral sinovenous thrombosis in children: another reason to treat iron deficiency anemia. Journal of Child Neurology 19: 526-531.

12. Akins PT, Glenn S, Nemeth PM, Derdeyn CP (1996) Carotid artery thrombus associated with severe iron-deficiency anemia and thrombocytosis. Stroke 27 1002-1005.

13. Kacer B, Hattenbach LO, Hörle S, Scharrer I, Kroll P, et al. (2001) Central retinal vein occlusion and nonarteritic ischemic optic neuropathy in 2 patients with mild iron deficiency anemia. Ophthalmologica 215: 128-131.

14. Kirkham TH, Wrigley PF, Holt JM (1971) Central retinal vein occlusion complicating iron deficiency anaemia. The British journal of ophthalmology 55: 777-780.

15. Stehle G, Buss J, Heene DL (1991) Noninfectious thrombosis of the superior sagittal sinus in a patient with iron deficiency anemia. Stroke 22: 414.

16. Donovan PB, Kaplan ME, Goldberg JD, Tatarsky I, Najean Y, et al. (1984) Treatment of polycythemia vera with hydroxyurea. American Journal of Hematology 17: 329-334.

17. Barbui T, Thiele J, Gisslinger H, Carobbio A, Vannucchi AM, et al. (2017) Diagnostic impact of the 2016 revised who criteria for polycythemia vera. American Journal of Hematology 92: 417-419.

18. Verstovsek S, Harrison CN, Kiladjian JJ, Miller C, Naim AB, et al. (2017) Markers of iron deficiency in patients with polycythemia vera receiving ruxolitinib or best available therapy. Leukemia Research 56: 52-59. 
Citation: Kellner A, Kellner V, Rajnics P, Karádi E, Illés A, et al. (2018) Low Mean Cell Haemoglobin is a Valuable Parameter of Thrombotic Risk Stratification in Patients with Polycythemia Vera. J Blood Lymph 8: 207. doi:10.4172/2165-7831.1000207

19. Tefferi A, Barbui T (2015) Polycythemia vera and essential thrombocythemia: 2015 update on diagnosis, risk-stratification and management. American Journal of Hematology 90: 162-173.

20. Landolfi R, Di Gennaro L (2008) Prevention of thrombosis in polycythemia vera and essential thrombocythemia. Haematologica 93: 331-335.

21. Kellner SV, Kellner Á, Haragh A, Dombi P, Karádi É, et al. (2016) Low mean cell hemoglobin is a reliable marker for iron deficiency screening. Orvosi Hetilap 157: 35-38.

22. d'Onofrio G, Chirillo R, Zini G, Caenaro G, Tommasi M, et al. (1995) Simultaneous measurement of reticulocyte and red blood cell indices in healthy subjects and patients with microcytic and macrocytic anemia. Blood 85: 818-823.

23. d'Onofrio G, Zini G, Ricerca BM, Mancini S, Mango G (1992) Automated measurement of red blood cell microcytosis and hypochromia in iron deficiency and beta-thalassemia trait. Archives of Pathology \& Laboratory Medicine 116: 84-89.

24. Schaefer RM, Schaefer L (1999) Hypochromic red blood cells and reticulocytes. Kidney International 55: S44-48.

25. Thomas $C$, Thomas $L$ (2002) Biochemical markers and hematologic indices in the diagnosis of functional iron deficiency. Clinical Chemistry 48: 1066-1076.

26. Mast AE, Blinder MA, Lu Q, Flax S, Dietzen DJ (2002) Clinical utility of the reticulocyte hemoglobin content in the diagnosis of iron deficiency. Blood 99 : 1489-1491.

27. Dombi P, Illés Á, Demeter J, Homor L, Simon Z, et al. (2016) Development of the Philadelphia negative chronic myeloproliferative neoplasia registry in Hungary. Orvosi Hetilap 157: 98-103.

28. Spivak JL, Silver RT (2008) The revised World Health Organization diagnostic criteria for polycythemia vera, essential thrombocytosis, and primary myelofibrosis: an alternative proposal. Blood 112: 231-239.

29. Gisslinger H, Gotic M, Holowiecki J, Penka M, Thiele J, et al. (2013) Anagrelide compared with hydroxyurea in WHO-classified essential thrombocythemia: the ANAHYDRET Study, a randomized controlled trial. Blood 121: 1720-1728.

30. Baxter EJ, Scott LM, Campbell PJ, East C, Fourouclas N, et al. (2005) Acquired mutation of the tyrosine kinase JAK2 in human myeloproliferative disorders. The Lancet 365: 1054-1061.

31. Larsen TS, Christensen JH, Hasselbalch HC, Pallisgaard N (2007) The JAK2 V617F mutation involves B-and T-lymphocyte lineages in a subgroup of patients with Philadelphia-chromosome negative chronic myeloproliferative disorders. British Journal of Haematology 136: 745-751.

32. Hartfield DS, Lowry NJ, Keene DL, Yager JY (1997) Iron deficiency: a cause of stroke in infants and children. Pediatric neurology 16: 50-53.

33. Tekin D, Yavuzer S, Tekin M, Akar N, Cin S (2001) Possible effects of antioxidant status on increased platelet aggregation in childhood iron-deficiency anemia. Pediatrics International 43: 74-77.

34. Akins PT, Glenn S, Nemeth PM, Derdeyn CP (1996) Carotid artery thrombus associated with severe iron-deficiency anemia and thrombocytosis. Stroke 27: 1002-1005.

35. Rajnics P, Kellner Á, Karádi É, Moizs M, Bödör C, et al. (2016) Increased Lipocalin 2 level may have important role in thrombotic events in patients with polycythemia vera and essential thrombocythemia. Leukemia Research 48: 101-106.

36. Kjeldsen L, Johnsen AH, Sengeløv H, Borregaard N (1993) Isolation and primary structure of NGAL, a novel protein associated with human neutrophil gelatinase. Journal of Biological Chemistry 268: 10425-10432.

37. Xu S, Venge $P$ (2000) Lipocalins as biochemical markers of disease. Biochimica et Biophysica Acta 1482: 298-307.

38. Schmidt-Ott KM, Mori K, Li JY, Kalandadze A, Cohen DJ, et al. (2007) Dua action of neutrophil gelatinase-associated lipocalin. Journal of American Society of Nephrology 18: 407-413.

39. Goetz DH, Willie ST, Armen RS, Bratt T, Borregaard N, et al. (2000) Ligand preference inferred from the structure of neutrophil gelatinase associated lipocalin. Biochemistry 39: 1935-1941.

40. Jiang W, Constante M, Santos MM (2008) Anemia upregulates lipocalin 2 in the liver and serum. Blood Cells, Molecules and Diseases 41: 169-174. 